\title{
KAJIAN BEBAN PENCEMARAN SALURAN DRAINASE (PARIT) TERHADAP BAGIAN HILIR SUNGAI KAPUAS DI KELURAHAN SUNGAI JAWI LUAR KECAMATAN PONTIANAK BARAT
}

\author{
Soni Dewantara ${ }^{11}$; Jhonny MTS ${ }^{21}$; Winardi ${ }^{1)}$ \\ ${ }^{1}$ Program Studi Teknik Lingkungan, Universitas Tanjungpura, Pontianak \\ 2Jurusan Teknik Sipil, Universitas Tanjungpura, Pontianak \\ E-mail :sonydewantara4892@gmail.com
}

\begin{abstract}
ABSTRAK
Pontianak Barat adalah Kecamatan dengan penduduk terbanyak yaitu 127.701 jiwa dengan kepadatan penduduk sebesar $7.592 \mathrm{jiwa} / \mathrm{km}^{2}$ dan laju angka pertumbuhan penduduk sebesar 1,86 \%. Semakin bertambahnya populasi penduduk maka semakin banyak aktivitas penduduk yang membuang limbah, baik secara langsung ke Sungai Kapuas maupun ke saluran drainase (parit) sehingga kualitas air Sungai Kapuas menjadi tercemar.

Penelitian ini bertujuan untuk mengetahui besarnya beban pencemaran pada beberapa saluran drainase (parit) di Kelurahan Sungai Jawi Luar Kecamatan Pontianak Barat dan mengetahui perkiraan besarnya potensi beban pencemar yang dihasilkan dari aktivitas domestik pada masing - masing saluran Drainase (Parit Gang Rambutan, Parit Gang Blitar, Parit Gang Tamang 2, Parit Gang Suka pinang, Parit Gang Jagung dan Parit Gang Teratai 1) tersebut dalam upaya menentukan pengendalian beban pencemar yang terjadi.

Tahapan penelitian ini yaitu pengumpulan data primer berupa dimensi saluran (lebar dan kedalaman), luas penampang basah, kecepatan aliran, debit aliran, pengambilan sampel air, perhitungan beban pencemaran dan analisis pengendalian beban pencemar. Pengambilan sampel kualitas air menggunakan metode grab sample (sampel sesaat) saat surut terendah yaitu pada tanggal 2 Maret 2014 pukul 18.49 WIB dan saat pasang tertinggi yaitu pada tanggal 3 Maret 2014 pukul 12.00 WIB dengan parameter pencemar yaitu BOD, COD, Total Phosfat, Total Nitrogen, Total Coliform, Suhu dan pH.

Hasil analisis diketahui total beban pencemaran dari ke-enam saluran drainase (parit) yang akan masuk ke Sungai Kapuas pada saat pasang adalah: BOD (436 kg/hari); COD (1.110 kg/hari); Total Phosfat (46 kg/hari); Total Nitrogen (123 kg/hari). Sedangkan pada saat surut total beban pencemaran dari ke-enam saluran drainase (parit) yang akan masuk ke Sungai Kapuas adalah: BOD (659 kg/hari); COD (2.291 kg/hari); Total Phosfat (139 kg/hari); Total Nitrogen $(676 \mathrm{~kg} / \mathrm{hari})$. Adapun besarnya potensi beban pencemaran yang dihasilkan dari aktifitas domestik hingga tahun 2034 adalah: BOD (1.608 kg/hari); COD (2.895 kg/hari); Total Phosfat (647 kg/hari); Total Nitrogen (108 $\mathrm{kg} /$ hari) dengan laju peningkatan potensi beban pencemaran setiap parameter adalah 9,21 \%. Adapun strategi pengendalian beban pencemaran air dilakukan dengan meningkatkan pengelolaan limbah melalui penyediaan sarana sanitasi, mensosialisasikan peraturan dan perundang - undangan yang berkaitan dengan pengelolaan air dan pengendalian pencemaran air, meningkatkan penyediaan sarana dan prasarana pendukung dalam pengawasan sumber - sumber pencemar dan melakukan pemantauan secara rutin terhadap kualitas air sungai/parit, serta meningkatkan layanan pengangkutan sampah dan meningkatkan layanan penyediaan air bersih.

Kata-kata kunci: Sungai Kapuas, Limbah Domestik, Beban Pencemaran, Pengendalian
\end{abstract}

\section{ABSTRACT}

Pontianak West is the District with the largest population is 127.701 inhabitants with a population density of 7.592 people $/ \mathrm{km}^{2}$ and the rate of population growth rate of 1,86\%. Increasing population size, the more activities that residents dispose of the waste, either directly to the Kapuas River and into the drainage channel (trench) so that the quality of the Kapuas River became polluted.

This study aims to determine the pollution load in some drainage channels (trenches) in the village of Sungai Jawi District of West Pontianak Affairs and know the approximate magnitude of the potential pollutant load generated from domestic activities on each - each drainage channel (trench Rambutan Gang, Gang Trenches Blitar, trenches 2 Tamang Gang, Gang Likes nut trenches, trenches and trench Corn Gang Gang Lotus 1) in its efforts to determine the pollutant load control happens.

Stages of this research is the collection of primary data in the form of channel dimensions (width and depth), wet cross-sectional area, flow velocity, flow rate, water sampling, calculation of pollution load and pollutant load control analysis. Water quality sampling using a grab sample (sample moment) the lowest tide that on March 2, 2014 
at 18:49 pm and the highest tide which is on March 3rd, 2014 at 12:00 pm by pollutant parameters ie BOD, COD, Total Phosfat, Total Nitrogen, Total Coliform, temperature and $\mathrm{pH}$.

The results of analysis show the total pollution load of the six drainage channel (ditch) that will go into the Kapuas River at high tide are: BOD (436 kg / day); COD (1.110 kg / day); Total Phosfat (46 kg / day); Total Nitrogen (123 kg / day). While at low total pollution load of the six drainage channel (ditch) that will go into the Kapuas River are: BOD (659 kg / day); COD (2.291 kg / day); Total Phosfat (139 kg / day); Total Nitrogen (676 kg / day). The magnitude of the potential pollution load generated from domestic activities until the year 2034 are: BOD (1.608 kg / day); COD (2.895 kg / day); Total Phosfat (647 kg / day); Total Nitrogen (108 kg / day) with the rate of increase of the potential pollution load of each parameter is $9,21 \%$. As for the water pollution load control strategy is done by improving waste management through the provision of sanitation facilities, socialize rules and regulations - regulations relating to water management and water pollution control, increasing the provision of facilities and infrastructure to support the monitoring sources - the sources of pollution and conduct regular monitoring of the water quality of the river / moat, and to improve the service of transporting waste and improve water services.

Keywords: Kapuas River, Domestic Waste, Pollution Charges, Control

\section{PENDAHULUAN}

Pontianak Barat merupakan salah satu contoh Kecamatan yang perkembangan penduduknya cukup pesat dengan berbagai aktivitas penduduk yang ramai, sangat berpengaruh terhadap buangan limbah domestik terhadap saluran pembuangannya. Pontianak Barat dulunya merupakan kawasan kebun kelapa, pertanian dan lain - lain. Sekarang dengan banyaknya permintaan akan papan maka sedikit demi sedikit lahan - lahan tersebut berubah menjadi pemukiman. Hal ini dapat dilihat dari perkembangan jumlah penduduknya yang semakin pesat sehingga mencapai 127.701 jiwa dengan kepadatan penduduk sebesar $7.592 \mathrm{jiwa} / \mathrm{km}^{2}$, dengan laju angka pertumbuhan penduduknya sebesar $1,86 \%$ per tahunnya (BPS Kota Pontianak, 2013) sehingga banyaknya pemukiman penduduk serta pembangunan infrastruktur lainnya seperti jalan, jembatan, perdagangan dan fasilitas penunjang lainnya yang telah menyebabkan alih fungsi lahan atau tata guna lahan berubah. Seiring dengan meningkatnya populasi penduduk di suatu wilayah maka semakin banyak juga kegiatan atau aktivitas penduduk di sepanjang aliran sungai, seperti bertambahnya pemukiman penduduk, keberadaan pasar, rumah sakit, dan lain lain menyebabkan menurunnya kualitas air di sungai tersebut sehingga menyebabkan air sungai tersebut menjadi tercemar.

Penelitian ini dilakukan untuk mengetahui jumlah beban pencemar yang akan masuk ke Sungai Kapuas dari beberapa saluran yang ada di Kota Pontinak khususnya di wilayah Kecamatan Pontianak Utara dan memperkirakan potensi beban pencemar yang akan terjadi hingga 20 tahun yang akan datang, sehingga dapat di lakukan penanganan yang tepat terhadap masing masing saluran berdasarkan jenis pencemaran dan juga tingkat pencemaranya.

\section{DASAR TEORI}

Pencemaran air adalah masuknya atau dimasukkannya mahluk hidup, zat, energi dan atau komponen lain ke dalam air oleh kegiaan manusia sehingga kualitas air turun sampai ke tingkat tertentu yang menyebabkan air tidak berfungsi lagi sesuai dengan peruntukannya. Kualitas air sungai dipengaruhi oleh kualitas pasokan air yang berasal dari daerah tangkapan sedangkan kualitas pasokan air dari daerah tangkapan berkaitan dengan aktivitas manusia yang ada di dalamnya (Wiwoho, 2005). Pengaruh penggunaan lahan pada masalah air terlihat pada penggunaan lahan antara lain permukiman, perdagangan/jasa atau industri di sekitar lokasi sumber air, sehingga segala aktivitas dan perubahan yang terjadi di kawasan tersebut memberi dampak pengaruh pada sumber air melalui jaringan aliran drainase baik alam maupun buatan yang menghubungkan antara kawasan tersebut dengan sumber air baku, dengan dipengaruhi oleh kondisi alam dan lingkungan antara lain bentuk topografi, kepadatan bangunan, jumlah penduduknya, kegiatan penduduknya dan jenis tanahnya (Sugiarto, 2005).

Menurut Peraturan Pemerintah No. 82 Tahun 2001 beban pencemaran adalah jumlah suatu pencemar yang terkandung di dalam air atau air limbah. Selain itu beban pencemaran juga didefinisikan 
sebagai bahan pencemar dikalikan kapasitas aliran air yang mengandung bahan pencemar, artinya adalah jumlah berat pencemar dalam satuan waktu tertentu, misalnya $\mathrm{kg} / \mathrm{hari}$.

\section{METODE PENELITIAN}

\section{A. TEMPAT DAN WAKTU}

Penelitian ini dilaksanakan di wilayah Kecamatan Pontianak Barat, tepatnya di Kelurahan Sungai Jawi Luar. Penelitian ini dilakukan pada bulan februari - Maret 2014. Data merupakan data primer yang diperoleh dari lapangan dan data sekunder yang diperoleh dari instansi terkait.

\section{B. ALAT DAN BAHAN}

Bahan - bahan yang diperlukan dalam penelitian ini antara lain sampel air permukaan dari masing - masing saluran, es batu sebagai pengawet sampel air dan larutan buffer untuk kalibrasi alat pH meter. Peralatan yang diperlukan dalam penelitian ini antara lain: GPS, bak ukur, botol sampel yang telah diberi label, current meter, pelampung kayu, pH meter, thermometer, meteran dan termos pendingin.

\section{PENGAMBILAN SAMPEL DAN PENGUKURAN}

Waktu pengambilan sampel air dilakukan dua kali, pada saat surut terendah yaitu pada tanggal 2 maret 2014 pukul 18.49 WIB dan saat pasang tertinggi yaitu pada tanggal 3 maret 2014 pukul 12.00 WIB.

\section{ANALISIS DATA}

Analisis yang dilakukan meliputi analisis beban pencemaran pada masing - masing saluran drainase (parit), analisis estimasi potensi beban pencemaran domestik dan pengendalian beban pencemaran di Kecamatan Pontianak Barat.

1. Analisis Beban Pencemaran Sungai/saluran (BPS)

Menghitung beban pencemaran masing - masing saluran drainase (parit), memerlukan data debit aliran. Debit masing - masing saluran drainase (parit) diperoleh dari hasil kali antara kecepatan aliran (V) dengan luas penampang (A) pada titik pengambilan sampel. Kemudian diperlukan data kualitas air masing - masing saluran drainase (parit), sehingga dilakukan pengambilan sampel pada satu titik setiap salurannya yaitu pada bagian hilir. Adapun sampel yang diambil adalah sampel sesaat dengan parameter yang diuji meliputi suhu, pH, BOD, COD, Total Phosfat, Total Nitrogen dan Total Coliform. Hasil uji parameter - parameter tersebut kemudian dibandingkan dengan baku mutu air sesuai Peraturan Pemerintah Republik Indonesia No. 82 Tahun 2001 tentang Pengelolaan Kualitas Air dan Pengendalian Pencemaran Air. Setelah itu dilakukan perhitungan beban pencemaran saluran dengan menggunakan persamaan berikut:

$B P S=(C s) \times Q \times 0,001$

2. Analisis Estimasi Potensi Beban Pencemaran Domestik (PBPD)

Sebelum dilakukan perhitungan estimasi potensi beban pencemaran untuk 20 tahun yang akan datang, terlebih dahulu dilakukan perhitungan untuk proyeksi jumlah penduduk, kepadatan penduduk, kepadatan penduduk dan perkiraan luas lahan pemukiman. setelah diketahui kepadatan penduduk, kemudian dilakukan perhitungan perkiraan potensi beban pencemaran domestik berdasarkan metode estimasi, yang dirumuskan dalam Peraturan Menteri LH No. 01 Tahun 2010 :

$P B P D=$ Luas $\times$ kepadatan penduduk $\times$ faktor emisi $\times 0,001$

3. Analisis Pengendalian Beban Pencemaran di Kecamatan Pontianak Barat

Pada penelitian ini dilakukan analisis prioritas strategi pengendalianpencemaran air berdasarkan data kondisi kualitas air dan pengamatan dilapangan.

\section{HASIL DAN PEMBAHASAN}

A. Analisis Beban Pencemaran Sungai/Saluran

- Analisis Debit Masing - masing Saluran

Menurut Peraturan Pemerintah No. 82 Tahun 2001 beban pencemaran adalah jumlah suatu pencemar yang terkandung di dalam air, untuk menghitung beban pencemaran diperlukan data debit 
aliran dan data kualitas masing - masing saluran drainase (parit). Hasil pengukuran debit pada masing - masing saluran drainase (parit) baik pada saat pasang maupun surut dapat dilihat pada tabel 1:

Tabel 1. Hasil Perhitungan Debit Saat Surut - Pasang

\begin{tabular}{lcccccc}
\hline & \multicolumn{3}{c}{ Surut } & \multicolumn{3}{c}{ Pasang } \\
\cline { 2 - 5 } Nama Saluran & $\begin{array}{c}\text { Kecepatan } \\
\text { Aliran } \\
\text { (m/detik) }\end{array}$ & $\begin{array}{c}\text { Luas } \\
\text { Penampa } \\
\text { ng Aliran } \\
(\mathrm{m} 2)\end{array}$ & $\begin{array}{c}\text { Q } \\
(\mathrm{m} 3 / \text { detik) }\end{array}$ & $\begin{array}{c}\text { Kecepatan } \\
\text { Aliran } \\
(\mathrm{m} / \text { detik) }\end{array}$ & $\begin{array}{c}\text { Luas } \\
\text { Penampang } \\
\text { Aliran (m2) }\end{array}$ & $\begin{array}{c}\text { Q } \\
\text { (m3/detik) }\end{array}$ \\
Gg. Rambutan & 0,064 & 2,88 & 0,222 & 0,044 & 3,96 & 0,209 \\
Gg. Blitar & - & 1,06 & - & - & 1,26 & - \\
Gg. Tamang 2 & 0,043 & 1,34 & 0,070 & 0,039 & 0,49 & 0,022 \\
Gg. Suka Pinang & 0,024 & 1,36 & 0,023 & 0,024 & 2,12 & 0,036 \\
Gg. Jagung & 0,064 & 0,77 & 0,039 & 0,035 & 1,44 & 0,040 \\
Gg. Teratai 1 & 0,069 & 2,13 & 0,169 & - & 2,60 & - \\
\hline
\end{tabular}

Berdasarkan tabel 1 di atas diketahui pada kondisi surut kecepatan aliran paling besar terdapat pada saluran drainase (parit) Gang Tearatai 1, sedangkan debit terbesar berasal dari saluran drainase (parit) Gang Rambutan. Pada kondisi pasang, kecepatan aliran terbesar terdapat pada saluran drainase (parit) Gang Rambutan, sedangkan debit terbesar berasal dari saluran drainase (parit) Gang Rambutan.

Tabel 2. Hasil Analisis Uji Kualitas Air

\begin{tabular}{|c|c|c|c|c|c|c|c|c|c|c|c|c|c|c|}
\hline \multirow{3}{*}{ Nama Sungai } & \multirow{3}{*}{$\begin{array}{l}\text { Luas } \\
\text { DTH } \\
\left(\mathbf{k m}^{2}\right)\end{array}$} & \multirow{3}{*}{$\begin{array}{c}\text { Luas } \\
\begin{array}{c}\text { DTH - } \\
\text { RTH }\end{array} \\
\left(\mathrm{km}^{2}\right)\end{array}$} & \multirow{3}{*}{$\begin{array}{c}\text { Jumlah } \\
\text { Pendu } \\
\text { duk } \\
\text { DTH } \\
\text { (2014) } \\
\text { (jiwa) }\end{array}$} & \multirow{3}{*}{$\begin{array}{c}\begin{array}{c}\text { Perkiraan } \\
\text { Luas } \\
\text { Pemukima } \\
\mathbf{n}\end{array} \\
\left(\mathbf{k m}^{2}\right)\end{array}$} & \multirow{3}{*}{$\begin{array}{c}\begin{array}{c}\text { Persent } \\
\text { ase Luas } \\
\text { Pemuki } \\
\text { man }\end{array} \\
(\%)\end{array}$} & \multirow{3}{*}{$\begin{array}{l}\text { Kepadata } \\
\text { Pendudu }\end{array}$} & \multirow{3}{*}{$\begin{array}{l}\text { Kondi } \\
\text { si } \\
\text { Aliran }\end{array}$} & \multicolumn{7}{|c|}{ Parameter } \\
\hline & & & & & & & & \multirow[t]{2}{*}{$\mathrm{pH}$} & \multirow{2}{*}{$\begin{array}{c}\text { Suhu } \\
\left({ }^{\circ} \mathrm{C}\right)\end{array}$} & \multirow{2}{*}{$\begin{array}{c}\text { BOD } \\
(\mathrm{mg} / \mathrm{l})\end{array}$} & \multirow{2}{*}{$\begin{array}{c}\text { COD } \\
(\mathrm{mg} / \mathrm{l})\end{array}$} & \multirow{2}{*}{$\begin{array}{c}\text { TP } \\
(\mathrm{mg} / \mathrm{l})\end{array}$} & \multirow{2}{*}{$\begin{array}{c}\mathrm{TN} \\
(\mathrm{mg} / \mathrm{l})\end{array}$} & \multirow{2}{*}{\begin{tabular}{|c}
$\begin{array}{c}\text { Total } \\
\text { Coliform }\end{array}$ \\
$\begin{array}{c}\text { (MPN/100 } \\
\mathrm{ml})\end{array}$ \\
\end{tabular}} \\
\hline & & & & & & & & & & & & & & \\
\hline \multirow{2}{*}{$\begin{array}{l}\text { Parit Gg. } \\
\text { Rambutan }\end{array}$} & \multirow{2}{*}{0,76} & \multirow{2}{*}{0,53} & \multirow{2}{*}{5.971} & \multirow{2}{*}{0,179} & \multirow{2}{*}{14,80} & \multirow{2}{*}{$\begin{array}{c}98.39 \\
9 \\
\end{array}$} & Surut & 5,7 & 27 & 14,91 & 48,19 & 2,03 & 14,789 & 5 \\
\hline & & & & & & & Pasang & 6,2 & 30 & 17,79 & 40,19 & 1,50 & 4,550 & 4 \\
\hline \multirow{2}{*}{ Parit Gg. Blitar } & \multirow{2}{*}{0,68} & \multirow{2}{*}{0,48} & \multirow{2}{*}{6.316} & \multirow{2}{*}{0,189} & \multirow{2}{*}{39,47} & \multirow{2}{*}{$\begin{array}{c}96.34 \\
1 \\
\end{array}$} & Surut & 5,3 & 27 & 33,89 & 43,33 & 5,66 & 15,927 & 10 \\
\hline & & & & & & & Pasang & 6,2 & 30 & 12,71 & 40,19 & 1,65 & 3,413 & 4 \\
\hline \multirow{2}{*}{$\begin{array}{l}\text { Parit Gg. } \\
\text { Tamang } 2\end{array}$} & \multirow{2}{*}{0,29} & & & & & 57.15 & Surut & 5,3 & 27 & 7,11 & 44,76 & 3,11 & 12,514 & 4 \\
\hline & & 0,20 & 3.441 & 0,103 & 51,61 & 1 & Pasang & 6,4 & 32 & 11,86 & 39,04 & 2,08 & 11,376 & 4 \\
\hline Parit Gg. Suka & 055 & 020 & 6040 & & & 109.8 & Surut & 5,1 & 27 & 17,79 & 47,72 & 5,29 & 19,339 & 17 \\
\hline Pari Gg. & & & & & & 85.98 & Surut & 5,2 & 26 & 14,40 & 57,33 & 3,96 & 13,651 & 10 \\
\hline Jagung & $0, / 2$ & 0,50 & $0.36 /$ & 0,191 & 38,20 & 3 & Pasang & 5,6 & 31 & 15,25 & 49,71 & 1,83 & 3,415 & 4 \\
\hline Parit Gg. & & & & & & 99.46 & Surut & 5,4 & 27 & 16,92 & 55,42 & 3,95 & 15,927 & 4 \\
\hline Teratai 1 & 0,96 & $0,6 /$ & $1.5 / 6$ & 0,221 & 33,82 & 6 & Pasang & 5,7 & 32 & 33,89 & 75,2 & 3,54 & 15,927 & 4 \\
\hline & & & & & & & Kelas I & $6-9$ & Deviasi 3 & 2 & 10 & 0,2 & 10 & 1000 \\
\hline & & & & & & & $\begin{array}{c}\text { Kelas } \\
\text { II }\end{array}$ & $6-9$ & Deviasi 3 & 3 & 25 & 0,2 & 10 & 5000 \\
\hline & & Mutu (P & 0. 82 Tah & un 2001) & & & $\begin{array}{c}\text { Kelas } \\
\text { III }\end{array}$ & $6-9$ & Deviasi 3 & 6 & 50 & 1 & 20 & 10000 \\
\hline & & & & & & & $\begin{array}{c}\text { Kelas } \\
\text { IV }\end{array}$ & $5-9$ & Deviasi 3 & 12 & 100 & 5 & 20 & 10000 \\
\hline
\end{tabular}

Menurut Yuliastuti (2011), nilai pH dipengaruhi oleh adanya buangan limbah organik dan anorganik ke perairan. Jika di lihat pada Tabel 2. dapat diketahui bahwa rata-rata $\mathrm{pH}$ air saat pasang lebih 
tinggi dibandingkan saat surut, hal ini dikarenakan kondisi pasang terjadi pada saat siang hari dimana rata - rata aktivitas domestik maupun non domestik terjadi pada siang hari. Hasil pengukuran tingkat keasaman $(\mathrm{pH})$ pada masing - masing saluran saat surut masih berada dalam rentang baku mutu kelas IV, sedangkan pada saat pasang $(\mathrm{pH})$ air pada saluran di wilayah studi masih berada dalam rentang baku mutu kelas II kecuali pada ketiga saluran drainase (parit) ini yang berada dalam rentang baku mutu kelas IV yakni saluran drainase (parit) Gang Suka Pinang, Gang Jagung dan Gang Teratai 1.

Tinggi rendah suhu air sungai dipengaruhi oleh suhu udara di sekitarnya, disamping itu intensitas paparan sinar matahari yang masuk ke badan air serta kerapatan vegetasi di sekitar bantaran air juga akan mempengaruhi suhu air sungai. Intensitas sinar matahari dipengaruhi oleh penutupan awan, musim, serta waktu dalam hari. Semakin banyak intensitas sinar matahari yang mengenai badan air maka akan membuat suhu air sungai semakin tinggi. Begitu pula semakin banyak dan semakin rapat vegetasi di sekitar bantaran air maka akan membuat suhu udara sekitar menjadi lebih rendah sehingga suhu air sungai juga semakin rendah (Agustiningsih, 2012). Hal tersebut sejalan dengan hasil penelitian, pada Tabel 2. menunjukkan suhu air saat kondisi pasang lebih tinggi dibandingkan dengan kondisi surut. Hal ini terjadi karena proses pasang terjadi pada waktu siang hari dengan kondisi cuaca yang panas, sementara kondisi surut terjadi pada malam hari.

Berdasarkan hasil uji kualitas air dari ke-enam saluran drainase (parit) di wilayah studi diketahui nilai BOD pada saat pasang telah melebihi baku mutu kelas air. Pada saat kondisi surut diketahui nilai BOD dari ke-enam saluran juga telah melebihi baku mutu kelas air. Secara umum konsentrasi BOD pada saat kondisi pasang lebih tinggi dibandingkan saat kondisi surut. Hal ini disebabkan pada kondisi pasang yang terjadi pada siang hari dimana aktifitas domestik lebih banyak terjadi pada siang hari, sedangkan nilai COD konsentrasinya lebih tinggi pada saat kondisi surut dibandigkan saat kondisi pasang, hal ini menunjukkan ada pengaruh pasang surut terhadap nilai COD. Selain karena dipengaruhi oleh pasang surut, kualitas air suatu perairan juga dipengaruhi oleh aktivitas - aktivitas yang ada pada daerah tangkapan hujan. Menurut Supangat, 2008 semakin kecil tutupan lahan dalam DTH serta semakin beragamnya jenis penggunaan lahan dalam DTH menyebabkan kondisi kualitas air sungai semakin buruk, terutama adanya aktivitas pertanian dan pemukiman. Berdasarkan hasil pengujian COD pada saat surut diketahui bahwa seluruh saluran drainase (parit) memenuhi baku mutu kelas IV dengan nilai COD tertinggi terdapat pada saluran drainase (parit) Gang Jagung dan konsentrasi COD terendah terdapat pada saluran drainase (parit) Gang Blitar. Sementara itu, pada saat kondisi pasang nilai CODnya masih memenuhi baku mutu kelas III kecuali pada saluran drainase (parit) Gang Jagung dan Teratai 1 yang masih memenuhi baku mutu kelas IV dengan nilai COD tertinggi terdapat pada saluran drainase (parit) Gang Teratai 1 dan yang terendah terdapat pada saluran drainase (parit) Gang Tamang 2.

Berdasarkan hasil uji kualitas air diketahui bahwa kadar total posfat pada ke-enam saluran di wilayah studi pada saat surut masih memebuhi baku mutu kelas IV dan pada saat kondisi pasang kadar total phosat pada ke-enam saluran di wilayah studi juga sama-sama masih memenuhi baku mutu kelas IV.

Berdasarkan hasil uji kualitas air yang telah dilakukan, diketahui konsentrasi nitrogen total pada ke-enam saluran drainase (parit) di wilayah studi pada saat surut ternyata masih memenuhi baku mutu kelas III dan pada saat kondisi pasang konsentrasi nitrogen total juga sama-sama masih memenuhi baku mutu kelas III.

Berdasarkan hasil uji kualitas air yang telah dilakukan, diketahui kandungan total coliform pada ke-enam saluran drainase (parit) di wilayah studi baik pasang maupun surut masih berada dalam ambang batas yang diizinkan Menurut Kuswandi (2001) dalam Feliatra (2002), menyatakan bahwa bakteri fecal masuk ke perairan melalui aliran sungai serta limpasan air hujan sehingga kelimpahan bakteri akan semakin tinggi pada saat hujan. Sementara itu dalam penelitian ini pengambilan sampel di lakukan pada musim kemarau, sehingga tidak terdapat limpasan air permukaan, diduga hal inilah yang menyebabkan bakteri coliform yang terukur pada masing - masing saluran sangat kecil. 
- Analisis Beban Pencemaran Masing - masing Saluran

Berdasarkan hasil perhitungan beban pencemar masing - masing parameter ke-enam saluran, diketahui bahwa pada saat penelitian ini dilakukan ternyata terdapat dua saluran drainase (parit) yakni saluran drainase (parit) Gang Blitar dan Gang Teratai 1 tidak berkontribusi dalam menyumbang beban pencemaran bagi Sungai Kapuas. Pada saluran drainase (parit) Gang Teratai 1 saat kondisi pasang terjadi kecepatan alirannya tidak terukur sehingga debit tidak dapat dihitung, sedangkan pada saluran drainase (parit) Gang Blitar pada saat kondisi pasang dan surut terjadi, kecepatan alirannya tidak terukur sehingga beban pencemaran BOD tidak dapat dihitung. Berikut grafik perbandingan beban pencemar tiap parameter pada ke-enam saluran drainase (parit), baik pasang maupun surut:

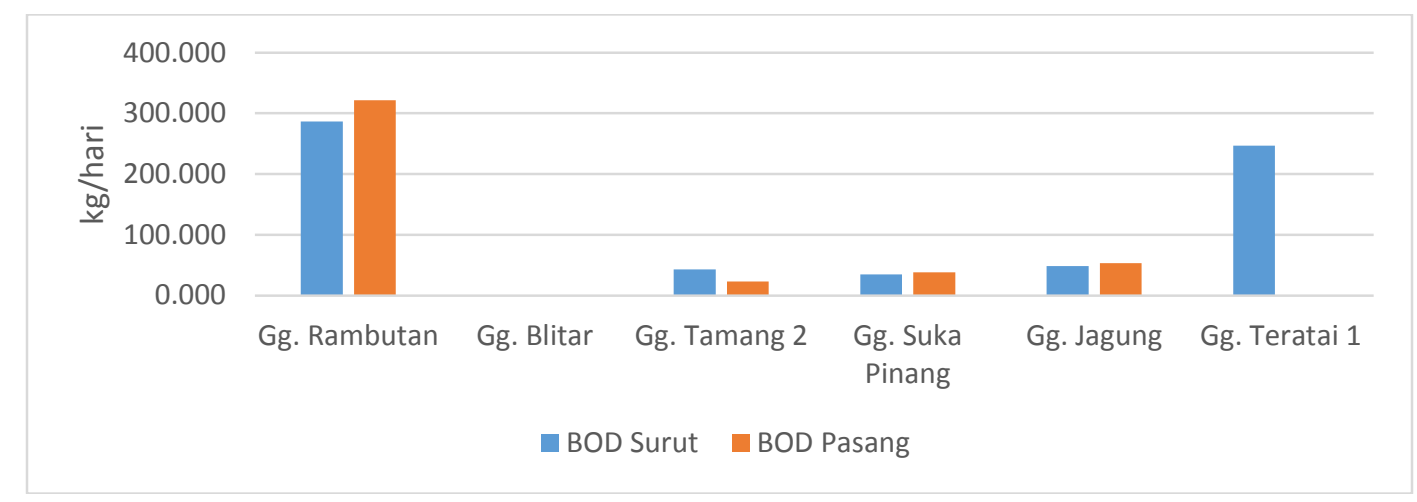

Gambar 1. Perbandingan Beban Pencemar BOD Pada Saat Pasang dan Surut

Berdasarkan grafik diatas dapat diketahui bahwa beban pencemaran BOD terbesar pada saat pasang berasal dari saluran Drainase (parit) Gang Rambutan (321 kg/hari) dan terkecil berasal dari saluran drainase (parit) Gang Tamang 2 (23 kg/hari), sedangkan pada saat surut beban pencemaran terbesar berasal dari saluran drainase (parit) Gang Rambutan $(286 \mathrm{~kg} / \mathrm{hari}$ ) dan terkecil berasal dari saluran drainase (parit) Gang Suka Pinang (35 kg/hari).

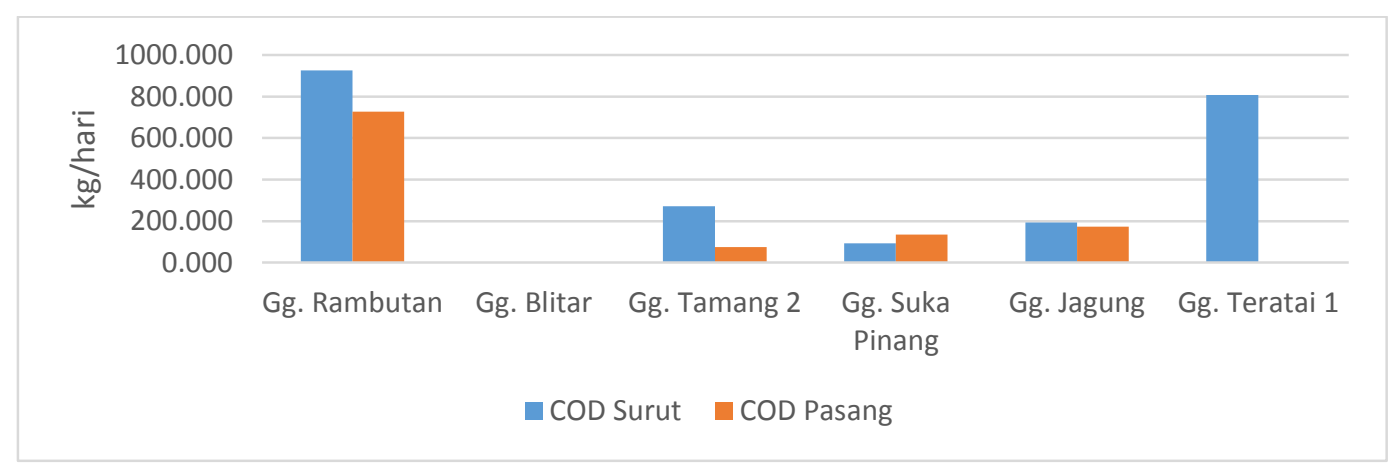

Gambar 2. Perbandingan Beban Pencemar COD Pada Saat Pasang dan Surut

Berdasarkan hasil analisis diketahui pada saat kondisi aliran pasang beban pencemaran COD terbesar berasal dari saluran drainase (parit) Gang Rambutan ( $726 \mathrm{~kg} /$ hari) dan terkecil berasal dari saluran drainase (parit) Gang Tamang 2 (75 kg/hari), sedangkan sedangkan pada saat surut beban pencemaran terbesar berasal dari saluran drainase (parit) Gang Rambutan (925 kg/hari) dan terkecil berasal dari saluran drainase (parit) Gang Suka Pinang (93 kg/hari). 


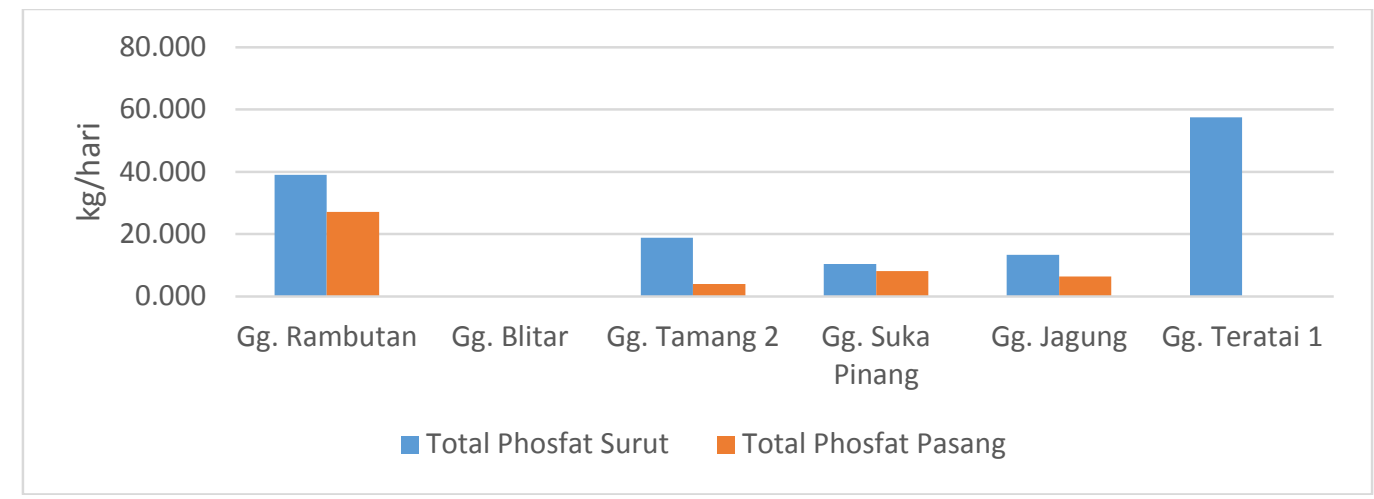

Gambar 3. Perbandingan Beban Pencemar Total Phosfat Pada Saat Pasang dan Surut

Berdasarkan grafik diatas dapat diketahui bahwa beban pencemaran Total Phosfat terbesar pada saat pasang berasal dari saluran Drainase (parit) Gang Rambutan (321 kg/hari) dan terkecil berasal dari saluran drainase (parit) Gang Tamang 2 (4 kg/hari), sedangkan pada saat surut beban pencemaran terbesar berasal dari saluran drainase (parit) Gang Teratai 1 (57 kg/hari) dan terkecil berasal dari saluran drainase (parit) Gang Suka Pinang (10 $\mathrm{kg} / \mathrm{hari})$.

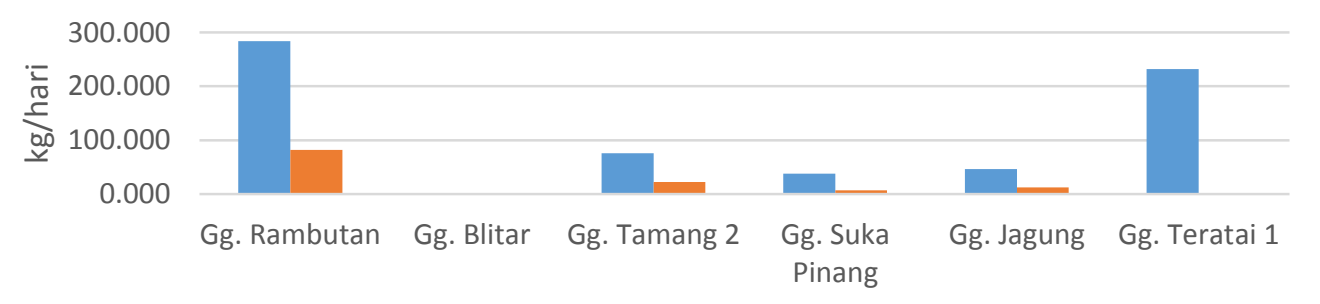

- Total Nitrogen Surut $\quad$ Total Nitrogen Pasang

Gambar 4. Perbandingan Beban Pencemar Total Nitrogen Pada Saat Pasang dan Surut

Berdasarkan grafik diatas dapat diketahui bahwa beban pencemaran Total Nitrogen terbesar pada saat pasang berasal dari saluran Drainase (parit) Gang Rambutan (82 kg/hari) dan terkecil berasal dari saluran drainase (parit) Gang Suka Pinang ( $7 \mathrm{~kg} / \mathrm{hari})$, sedangkan pada saat surut beban pencemaran terbesar berasal dari saluran drainase (parit) Gang Rambutan 1 (284 kg/hari) dan terkecil berasal dari saluran drainase (parit) Gang Suka Pinang (38 kg/hari).

Besar kecilnya beban pencemaran yang terjadi dipengaruhi banyak faktor. Selain sumber pencemar, faktor lain yang mempengaruhi besar kecilnya beban pencemar yang terjadi saat itu antara lain kondisi cuaca saat pengambilan sampel air, waktu pengambilan sampel air, titik pengambilan sampel air, kondisi pasang surut, kecepatan aliran dan debit.

Berdasarkan hasil perhitungan beban pencemaran pada ke-enam saluran yang diteliti dapat diketahui bahwa total beban pencemaran yang akan masuk ke Sungai Kapuas dapat dilihat pada tabel 3:

Tabel 3. Total Beban Pencemaran yang akan Masuk ke Sungai Kapuas Saat Pasang - Surut

\begin{tabular}{lcc}
\hline \multicolumn{1}{c}{ Parameter Beban Pencemaran } & Pasang & Surut \\
\hline BOD (kg/hari) & 436 & 659 \\
COD (kg/hari) & 1.11 & 2.291 \\
Total Phosfat (kg/hari) & 46 & 139 \\
Total Nitrogen (kg/hari) & 123 & 676 \\
\hline
\end{tabular}




\section{B. Analisis Estimasi Potensi Beban Pencemaran Domestik}

Perhitungan beban pencemaran penduduk dlakukan untuk kondisi tahun 2014 dan proyeksi 20 tahun yang akan datang dengan interval waktu 5 tahun. Proyeksi jumlah penduduk dilakkan dengan metode proyeksi pertumbuhan penduduk, sedangkan untuk menentukan luas lahan yang digunakan sebagai pemukiman diasumsikan setiap rumah tangga terdiri dari 5 orang dengan luas lahan untuk satu rumah tangga adalah $150 \mathrm{~m}^{2}$. Hasil perhitungan proyeksi jumlah penduduk dan luas lahan sebagai pemukiman pada masing - masing daerah tangkapan hujan dapat dilihat pada tabel 4.

Tabel 4. Hasil Proyeksi Jumlah Penduduk dan Perkiraan luas Lahan Pemukiman (2014-2034)

\begin{tabular}{|c|c|c|c|c|c|c|c|c|c|c|c|c|}
\hline \multirow{3}{*}{ Nama sungai } & \multirow{3}{*}{$\begin{array}{c}\text { Luas } \\
\text { DTH } \\
\left(\mathrm{km}^{2}\right)\end{array}$} & \multirow{3}{*}{$\begin{array}{c}\text { Luas } \\
\text { DTH - } \\
\text { RTH } \\
30 \% \\
\left(\mathrm{~km}^{2}\right) \\
\end{array}$} & \multirow{2}{*}{\multicolumn{5}{|c|}{ Jumlah Penduduk (Jiwa) }} & \multirow{2}{*}{\multicolumn{5}{|c|}{ Luas Pemukiman $\left(\mathrm{km}^{2}\right)$}} \\
\hline & & & & & & & & & & & & \\
\hline & & & 2014 & 2019 & 2024 & 2029 & 2034 & 2014 & 2019 & 2024 & 2029 & 2034 \\
\hline P. Gang Rambutan & 0,76 & 0,53 & 5.971 & 6.547 & 7.179 & 7.872 & 8.632 & 0,18 & 0,20 & 0,22 & 0,24 & 0,26 \\
\hline P. Gang Blitar & 0,68 & 0,48 & 6.316 & 6.926 & 7.595 & 8.328 & 9.131 & 0,19 & 0,21 & 0,23 & 0,25 & 0,27 \\
\hline P. Gang Tamang 2 & 0,29 & 0,20 & 3.441 & 3.773 & 4.137 & 4.536 & 4.974 & 0,10 & 0,11 & 0,12 & 0,14 & 0,15 \\
\hline P. Gang Suka pinang & 0,55 & 0,39 & 6.048 & 6.632 & 7.272 & 7.974 & 8.744 & 0,18 & 0,20 & 0,22 & 0,24 & 0,26 \\
\hline P. Gang Jagung & 0,72 & 0,50 & 6.367 & 6.982 & 7.656 & 8.395 & 9.205 & 0,19 & 0,21 & 0,23 & 0,25 & 0,28 \\
\hline P. Gang Teratai 1 & 0,96 & 0,67 & 7.576 & 8.308 & 9.110 & 9.989 & 10.953 & 0,23 & 0,25 & 0,27 & 0,30 & 0,33 \\
\hline
\end{tabular}

Setelah diketahui jumlah penduduk, kepadatan penduduk dan luas lahan yang dimanfaatkan sebagai lahan pemukiman pada setiap daerah tangkapan hujan,kemudian dilakukan perhitungan perkiraan potensi beban pencemaran domestik di wilayah kelurahan Sungai Jawi Luar Kecamatan Pontianak Barat hingga tahun 2034.

Tabel 5. Hasil Perhitungan Potensi Beban Pencemar (2014-2034)

\begin{tabular}{lccccc}
\hline & \multicolumn{5}{c}{ Potensi Beban Pencemaran (kg/hari) } \\
\cline { 2 - 6 } & 2014 & 2019 & 2024 & 2029 & 2034 \\
\hline BOD & 1.044 & 1.145 & 1.256 & 1.377 & 1.608 \\
COD & 2.002 & 2.196 & 2.408 & 2.640 & 2.895 \\
Total Phosfat & 447 & 490 & 538 & 589 & 646 \\
Total Nitrogen & 75 & 82 & 90 & 98 & 108 \\
\hline
\end{tabular}

Berdasarkan Tabel 5. Dapat diketahui laju peningkatan total potensi potensi beban pencemaran dari ke-enam saluran drainase (parit) tersebut. Berikut adalah grafik yang menunjukkan potensi beban pencemaran yang akan masuk ke Sungai Kapuas dari ke-enam saluran drainase (parit) yang tedapat di Keluarahan Sungai Jawi Luar Kecamatan Pontianak Barat: 


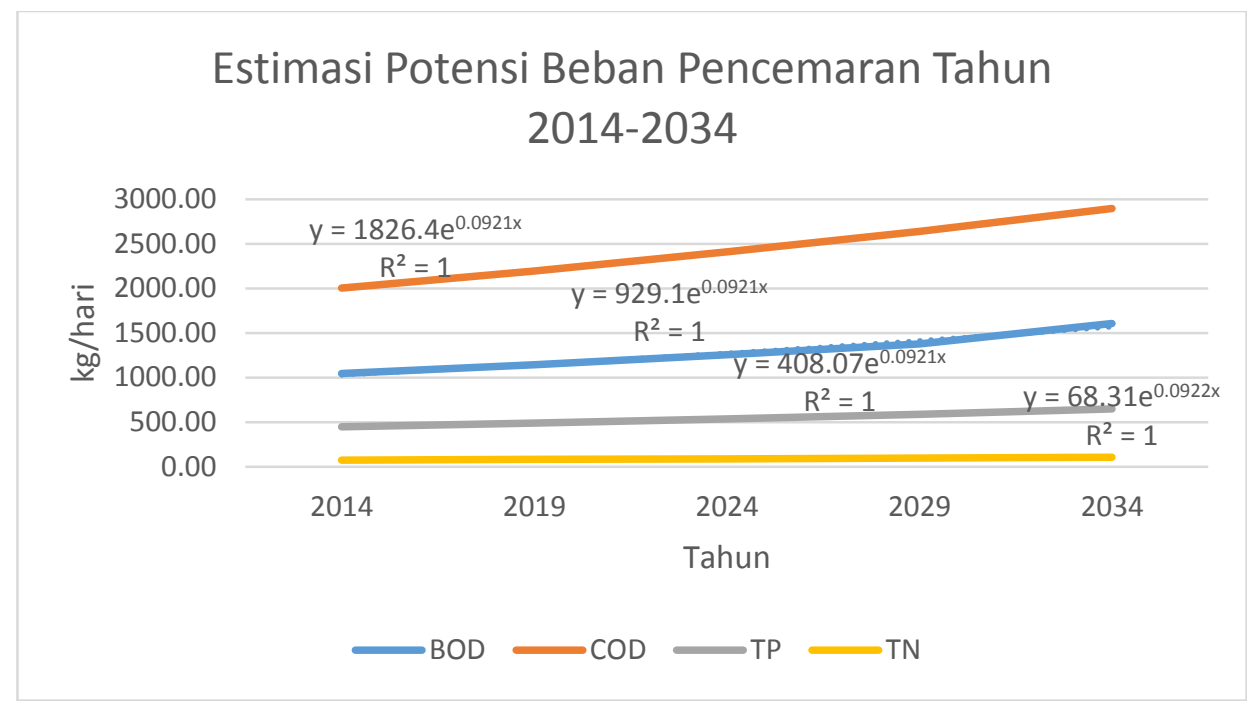

Gambar 5. Estimasi Potensi Beban Pencemaran (2014-2034)

Dari grafik tersebut dapat diketahui laju peningkatan beban pencemar masing - masing parameter adalah sama yaitu 9,21\% untuk setiap parameternya.

\section{Pengendalian Beban Pencemaran Domestik di Wilayah Kecamatan Pontianak Barat}

Berdasarkan hasil analisis terhadap beban pencemaran dari enam saluran drainase (parit) yang terdapat di Kelurahan Sungai Jawi Luar Kecamatan Pontianak Barat yang bermuara ke Sungai Kapuas, beban pencemaran yang terjadi pada saluran drainase (parit) tersebut cukup tinggi. Hal ini ditunjukkan dengan adanya parameter pencemar yang melebihi baku mutu yang diizinkan. Adapun cara pengendalian pencemaran air sungai atau saluran drainase (parit) yang tepat yaitu :

- Perubahan prilaku masyarakat :

a. Tidak membuang sampah atau limbah cair secara langsung ke saluran drainase (parit) sungai, laut dll.

b. Tidak menggunakan saluran drainase (parit) maupun sungai untuk tempat MCK, mencuci truk, mobil dan sepeda motor.

c. Tidak menggunakan saluran drainase (parit) maupun sungai untuk wahana memandikan ternak dan sebagai tempat kakus.

- Meningkatkan pengelolaan limbah melalui penyediaan sarana sanitasi dan instalasi pengolahan air limbah secara komunal.

- Melakukan pemantauan secara rutin terhadap kualitas air sungai/parit (saluran drainase)

- Mensosialisasi peraturan dan perundang - undangan yang berkaitan dengan pengelolaan air dan pengendalian pencemaran air kepada seluruh masyarakat.

- Melakukan kegiatan normalisasi seluruh parit (saluran drainase) yang ada di Kota Pontianak seperti pengerukan dan membersihkan sampah yang terdapat pada parit (saluran drainase).

\section{KESIMPULAN}

1. Total beban pencemaran dari ke-lima saluran drainase (parit) yang terdapat di Kelurahan Sungai Jawi Luar Kecamatan Pontianak Barat pada saat pasang adalah : BOD (436 kg/hari); COD (1.110 kg/hari); Total Phosfat (46 kg/hari); Total Nitrogen (123 kg/hari), sedangkan pada saat surut total beban pencemaran dari ke-lima saluran drainase (parit) yang terdapat di Kelurahan Sungai Jawi Luar Kecamatan Pontianak Barat pada saat pasang adalah : BOD (659 kg/hari); Parameter COD (2.291 $\mathrm{kg} /$ hari );Total Phosfat (139 kg/hari); Total Nitrogen (676 kg/hari). 
2. Besarnya potensi beban pencemaran yang akan dihasilkan dari kegiatan domestik masing - masing saluran drainase (parit) yang terdapat di Kelurahan Sungai Jawi Luar Kecamatan Pontianak Barat hingga tahun 2034 adalah : BOD (1.608 kg/hari); COD (2.895 kg/hari); Total Phosfat (647 kg/hari); Total Nitrogen (108 kg/hari) dengan laju peningkatan potensi beban pencemaran setiap parameter adalah sebesar $9,21 \%$.

3. Cara pengendalian pencemaran air sungai atau saluran drainase (parit) yang tepat yaitu :

- Perubahan prilaku masyarakat :

d. Tidak membuang sampah atau limbah cair secara langsung ke saluran drainase (parit) sungai, laut dll.

e. Tidak menggunakan saluran drainase (parit) maupun sungai untuk tempat MCK, mencuci truk, mobil dan sepeda motor.

f. Tidak menggunakan saluran drainase (parit) maupun sungai untuk wahana memandikan ternak dan sebagai tempat kakus.

- Meningkatkan pengelolaan limbah melalui penyediaan sarana sanitasi dan instalasi pengolahan air limbah secara komunal.

- Melakukan pemantauan secara rutin terhadap kualitas air sungai/parit (saluran drainase)

\section{UCAPAN TERIMA KASIH}

Ucapan terima kasih saya sampaikan kepada Bapak Dr. Ir. Johnny MTS, M.Sc dan Bapak Winardi, ST. MT sebagai pembimbing utama dan pembimbing pendamping serta Bapak Ir. H. Nasrullah, MT dan Ibu Isna Apriani, ST. M.Si sebagai penguji utama dan penguji pendamping yang telah memberikan bimbingan, masukan dan diskusi intensif khususnya mengenai isi dari skripsi ini.

\section{REFERENSI}

Agustiningsih, Dyah. 2012. Kajian Kualitas Air Sungai Blukar Kabupaten Kendal dalam Upaya Pengendalian Pencemaran Air Sungai. Tesis. Program Magister Ilmu Lingkungan, Program Pasca Sarjana, Universitas Diponegoro. Semarang. http://eprints.undip.ac.id/36856/. dikunjungi 5/9/2013

Feliatra, 2002, Sebaran Bakteri Escherichia coli di Perairan Muara Sungai Bantan Tengah Bengkalis Riau. Biogen. vol 1, hal 178-181

Supangat, A. B. 2008. Pengaruh berbagai Penggunaan Lahan Terhadap Kualitas Air Sungai di Kawasan Hutan Pinus di Gombong, Kebumen, Jawa Tengah. Jurnal Penelitian Hutan dan Konservasi Alam. Vol.5. No.3. pp 267-276

Yuliastuti, Etik. 2011. Kajian Kualitas Air Sungai Ngringo Kranganyar dalam Upaya pengendalian Pencemaran Air. Tesis. Program magister Ilmu Lingkungan. Program Pasca Sajarna. Universitas Diponegoro. Semarang. www. docstoc. com/ docs/ 149624140 /ETIK_YULIASTUTI_TESIS. dikunjungi 5/9/2013

Wiwoho. 2005. Model Identifikasi Daya Tampung Beban Cemaran Sungai dengan QUAL2E.Tesis. Universitas Diponegoro. Semarang

Sugiarto. 2005. Dasar-Dasar Pengelolaan Air Limbah. UI-Press. Jakarta 
